Journal of Social Sciences 5(4): 283-291, 2009

ISSN 1549-3652

(C) 2009 Science Publications

\title{
Amanah Saham National Berhad'S Promotional Strategies and its Relationship with Customer Motivation
}

\author{
${ }^{1}$ A. Yahaya, ${ }^{2}$ Noordin Yahaya ${ }^{1}$ J. Ramli, ${ }^{1}$ Y. Boon and ${ }^{1}$ M.N. Abd Ghaffar \\ ${ }^{1}$ Faculty of Education, University Technology Malaysia, Malaysia \\ ${ }^{2}$ University Technology Mara Melaka, Malaysia
}

\begin{abstract}
Problem statement: Every single company needs strategies in order to survive or to become a leader in the market nowadays, therefore a study towards findings the suitable strategies for Permodalan National Berhad had been carried out. Approach: The purpose of the study was to determine the types of ASNB's promotional strategies, to identify the level of effectiveness promotional tools used by Amanah Saham National Berhad (ASNB), to describe the correlations between ASNB's promotional strategies with customer motivation to invest and to examine the effect of the promotional tools with the customer motivation to invest in ASNB's products. Results: The findings from the study found that several strategies should be recommended to Amanah Saham National Berhad (ASNB). Firstly, ASNB should increase sales promotion such as high income distribution/dividend, offer scheme 'bantuan khairat kematian' to the investors, offer fixed and variable price as well as withdrawal or savings at any time for the investors as this can really encourage Bumiputera and non Bumiputera to invest in ASNB. Secondly, the information about PNB should be more advertise in television and newspaper since people are always see and read this two medium. The advertisement also should be more creative and attractive. Conclusion: Furthermore, PNB should hire more sales executives and hire individual agents as the strategy to boost up ASNB's sales.
\end{abstract}

Key words: Promotional strategies, level of effectiveness, customer motivation and promotional tools

\section{INTRODUCTION}

Unit trust funds are investment products created by asset management companies, to pool resources from individual investors and invest in diversified portfolio of securities, with the purpose of adding value to their financial wealth in the future period. While the earliest unit trust fund was created in the newly independent Malaya around the year 1959, followed by the introduction of subsequent funds in 1966, 1967 and 1977, the development of fund management industry in 60s and 70s had been retarded, due to lack of push and pull factors from institutional settings. The launching of Amanah Saham National (ASN) unit trust funds in 1981 has provided an impetus for new growth in fund management industry ${ }^{[1]}$.

The unit trust industry in Malaysia was first established by British investors in 1959 with the introduction of the Malayan Unit Trust Ltd. It is called unit trust instead of mutual fund because the ownership of the fund is divided into units of entitlement. Initially, the growth of the unit trust in Malaysia was very slow due to lack of public interest. The turning point for the industry was when the Malaysian government decided to enter into the industry by launching a government sponsored unit trust known as Amanah Saham National (ASN). The initial intention of launching the unit trust was to help improve the indigenous Malays' (Bumiputera's) social-economic status. Since then, the growth of the unit trusts (government and private funds) has been tremendous particularly during the period of 1991-1996, although the rapid development of the industry was slightly hindered by the 1997 Asian Financial Crisis. The rapid growth of the unit trust industry could be observed from the number of management companies from 13 in 1992 to more than 50 in 2007. Similarly, the number of funds approved has also increased for the same period. A number of factors have jointly contributed to the rapid expansion of the industry and those include strong economic and good stock market performance, expansion of the local stock market and success of the privatization companies.

Malaysia introduced the unit trust concept relatively early compared to its Asian neighbors, when, in 1959, a unit trust was first established by a company

Corresponding Author: Azizi Yahaya, Faculty of Education, University Technology Malaysia 81310 UTM Skudai Johor, Malaysia Tel: +60127570298 Fax: +607550542 
called Malayan Unit Trust Ltd. The unit trust industry in Malaysia has therefore a history of more than four (4) decades. The development of this industry can be presented in chronological order as follows:

The development of unit trusts: The first two decades in the history of the unit trust industry were characterized by slow growth in the sales of units and a lack of public interest in the new investment product. Only five unit trust management companies were established, with a total of 18 funds introduced over that period. The industry was regulated by several parties including the Registrar of Companies, The Public Trustee of Malaysia, Bank Negara Malaysia and the Ministry of Domestic Trade and Consumer Affairs.

The 1970s also witnessed the emergence of state government sponsored unit trusts, in response to the Federal Government's call to mobilize domestic household savings.

This period marks the entry of government participation in the Unit Trust Industry and the formation of a Committee to regulate the unit trust industry, called the Informal Committee for Unit Trust Funds, comprising representatives from the Registrar of Companies (ROC), the Public Trustee of Malaysia, Bank Negara Malaysia (BNM) and the Capital Issues Committee (CIC). The 1980s marked a significant development in the history of the industry when the Skim Amanah Saham National (ASN) was launched by Permodalan National Berhad (PNB) in 1981. Despite only 11 funds being launched during this period, the total units subscribed by the public swelled to an unprecedented level because of the overwhelming response to ASN.

This period witnessed the fastest growth of the unit trust industry in terms of the number of new management companies established and funds under management. The centralization of industry regulation, with the establishment of the Securities Commission on 1 March 1993, coupled with the implementation of the Securities Commission (Unit Trust Scheme) Regulations in 1996 and extensive marketing strategies adopted by the ASN and ASB (Amanah Saham Bumiputera), played key roles in making unit trusts household products in Malaysia. Consequently, the total asset value of funds under management grew more than threefold from RM15.72 billion at the end of 1992 to RM59.95 billion at the end of 1996. The period also saw greater product innovation and deregulation of the industry. Although the pace of growth of local unit trust funds has moderated since the financial crisis of 1997-1998, it has nevertheless maintained its upward trend.
Even though Amanah Saham National stills the leading the market, the actual fact is the major competitors are trying to narrowing the gap and finally grab the leading company. As Public Mutual Berhad now had been awarded as the number one unit trust company in Malaysia based on the variable price products. Generally, Amanah Saham National Berhad (ASNB) can be a market leader is because of the fixed price products where the other management companies do not offer at all. This make Amanah Saham National Berhad different from other management companies since it has the fixed price products as well as variable price which this fixed price products or funds are more trustable compared to variable price products. ASNB is responsible to manage ten types of investment schemes which is Amanah Saham Bumiputera (ASB), Amanah Saham National (ASN), Amanah Saham National (ASN 2), Amanah Saham National 3 Imbang (ASN 3 Imbang), Amanah Saham Wawasan 2020 (ASW 2020), Amanah Saham Didik (ASD), Amanah Saham Malaysia (ASM) and Amanah Saham Gemilang (ASGPendidikan, ASG-Kesihatan and ASG-Persaraan).

Research objectives: The research objective is derived from the problem definition and it's explains the purpose of the research in measurable terms, as well as defining what standards the research should accompanied. Such objectives help ensure that the research projects will be manageable in size in some instances the business problems and the project's research objectives are identical.

The objectives in this research are as follows:

- To identify the various type of promotional strategy as perceived by customers that being used by ASNB

- To evaluate the levels of the effectiveness as perceived by customers for each of the strategies done by ASNB

- To determine the correlations of promotional strategies with customer motivation to invest in ASNB

- To identify the effect of promotional strategies towards customer motivation to invest in ASNB

- To identify promotional strategies that ASNB can be implement in order to motivate more investors to invest in ASNB

\section{MATERIALS AND METHODS}

Marketing research is the systematic and objective identification, collection, analysis, dissemination and use of information for the purpose of improving 
decisions making related to the identification and solution of the problem ${ }^{[2]}$. Marketing research is defined as the systematic and objective process of generating information to aid in marketing decisions ${ }^{[3]}$.

The following topics will look at the various areas of research methodology undertaken for this study. The topics include the choice of area under study, the source of data, sampling techniques and methods of data analysis. This study focuses on the ASNB's promotional strategies and its relationship with customer motivation.

Sampling is actually a technique to identify group of cases, participants, events or records constituting a portion of the target population, carefully selected to represent that population and the propose of the following rules of thumbs for determining the sample size: Sample sizes larger than 30 and less than 500 are appropriate for most research ${ }^{[4]}$. Questionnaire refers to a survey instrument and is a structured technique for collecting data which consist of a series of questions, written or verbal, to which a respondents replies. Questionnaire had been constructed and distributed randomly to respondents within specified area. Willing respondents were asked to complete as soon as the questionnaire were given. The advantage of using time limitations is that researcher can be able to get fast and quick responds.

These questionnaires were designed in English and Malay. The purpose of designed the questions by using two languages is to facilitate the customers to understand the questions better. In this study, close ended questionnaire been used to collect data from population. Close ended question is to obtain some information related to customer opinion or suggestion towards the study.

\section{RESULTS}

Respondents' knowledge about ASNB's products and promotional strategies: Table 1 shows the respondents' knowledge about ASNB's products. All respondents which are 90 respondents knew about ASNB's products and do invest in ASNB's products. At present, ASNB offered ten products. They are Amanah Saham Bumiputera (ASB), Amanah Saham Wawasan 2020 (ASW 2020), Amanah Saham Malaysia (ASM), Amanah Saham Didik (ASD), Amanah Saham National (ASN), Amanah Saham National 2 (ASN 2), Amanah Saham National 3 (ASN 3), Amanah Saham Gemilang-Health (ASG-Health), Amanah Saham Gemilang-Retirement (ASG-Retirement) and Amanah Saham Gemilang-Education (ASG-Education).

As we can see, majority of the respondents choose to invest in ASB compared to other products where 52 respondents $(74.3 \%)$ choose to invest in that product.
Table 1: Respondents choice of investment in ASNB products by frequency and percentage

\begin{tabular}{|c|c|c|c|c|c|c|c|}
\hline ASNB products & Yes (f) & No (f) & $\mathrm{n}$ & Yes $(\%)$ & No $(\%)$ & Total $(\%)$ & Means \\
\hline ASB & 52 & 18 & 70 & 74.3 & 25.7 & 100 & 0.74 \\
\hline ASW 2020 & 21 & 49 & 70 & 30.0 & 70.0 & 100 & 0.30 \\
\hline ASM & 23 & 47 & 70 & 32.9 & 67.1 & 100 & 0.33 \\
\hline ASD & 7 & 63 & 70 & 10.0 & 90.0 & 100 & 0.10 \\
\hline ASN & 23 & 47 & 70 & 32.9 & 67.1 & 100 & 0.33 \\
\hline ASN 2 & 5 & 65 & 70 & 7.1 & 92.9 & 100 & 0.07 \\
\hline ASN 3 & 6 & 64 & 70 & 8.6 & 91.4 & 100 & 0.09 \\
\hline ASG-education & 3 & 67 & 70 & 4.3 & 95.7 & 100 & 0.04 \\
\hline ASG-health & 5 & 65 & 70 & 7.1 & 92.9 & 100 & 0.07 \\
\hline ASG-retirement & 5 & 65 & 70 & 7.1 & 92.9 & 100 & 0.07 \\
\hline
\end{tabular}

Table 2: Number of investment in ASNB products by frequency and percentage

ASNB products choose

\begin{tabular}{lcc} 
by respondents & Frequency & Percentage \\
\hline One product & 36.0 & 51.4 \\
Two products & 15.0 & 21.4 \\
Three products & 6.0 & 8.6 \\
Four products & 8.6 & 6.0 \\
Five products & 2.9 & 2.0 \\
Six products & 3.0 & 4.3 \\
Seven products & 2.0 & 2.9 \\
\hline Total & 70.0 & 100.0 \\
\hline
\end{tabular}

Both ASM and ASN products (32.9\%) choose by 23 of the respondents respectively for their investment products and followed by 21 of the respondents with the percentage of $30 \%$ choose to invest in ASW 2020.

While there are 7 and 6 of the respondents choose to invest in ASD and ASN 3 as well as only 5 respondents choose to invest in other 3 products which is ASN 2, ASG-Health and ASG-Retirement. Finally, only 3 of respondents $(4.3 \%)$ choose to invest in ASGEducation. This can be concluded that the top five choice of the ASNB products is ASB, ASM, ASN, ASW 2020 and ASD while the other four products is not preferred by the investors.

Table 2 shows the frequency and percentage of ASNB products that customers choose to invest. Majority of the respondents choose to invest in one of ASNB products only with the percentage of $51.4 \%$ (36 respondents). But there are also respondents choose to invest in more than one product in ASNB. Fifteen respondents have invested in two out of ten ASNB products, followed by 6 respondents choose to invest in 3 and 4 ASNB products respectively while the others choose to invest in more than four ASNB products.

Table 3 shows the frequency, mean, standard deviation and rank of respondents' heard about ASNB products. There are ten products offered by ASNB in order to give option to their investors and the products are categorized by two types which is fixed and variable price. The fixed price included Amanah Saham Bumiputera (ASB), Amanah Saham Wawasan 2020 (ASW 2020), Amanah Saham Malaysia (ASM) and Amanah Saham Didik (ASD). 
Table 3: Frequency, mean, standard deviation and rank for respondents' heard about ASNB products

\begin{tabular}{|c|c|c|c|c|c|c|c|c|c|}
\hline \multirow{2}{*}{$\begin{array}{l}\text { ASNB } \\
\text { Products }\end{array}$} & \multicolumn{5}{|c|}{ Scale } & \multirow[b]{2}{*}{ Mean } & \multirow{2}{*}{$\begin{array}{l}\text { Std. } \\
\text { Dev. }\end{array}$} & \multirow[b]{2}{*}{$\mathrm{n}$} & \multirow[b]{2}{*}{ Rank } \\
\hline & 0 & 1 & 2 & 3 & 4 & & & & \\
\hline ASB & 0 & 2 & 13 & 22 & 33 & 3.23 & 0.854 & 70 & 1 \\
\hline ASW 2020 & 3 & 9 & 12 & 26 & 20 & 2.73 & 1.141 & 70 & 2 \\
\hline ASM & 5 & 14 & 14 & 18 & 19 & 2.46 & 1.282 & 70 & 3 \\
\hline ASD & 4 & 21 & 22 & 17 & 6 & 2.00 & 1.063 & 70 & 6 \\
\hline ASN & 2 & 10 & 14 & 29 & 15 & 1.64 & 1.064 & 70 & 7 \\
\hline ASN 2 & 6 & 19 & 18 & 20 & 7 & 2.04 & 1.148 & 70 & 4 \\
\hline ASN 3 & 7 & 20 & 16 & 19 & 8 & 2.01 & 1.198 & 70 & 5 \\
\hline $\begin{array}{l}\text { ASG- } \\
\text { Education }\end{array}$ & 10 & 31 & 13 & 11 & 5 & 1.57 & 1.137 & 70 & 8 \\
\hline $\begin{array}{l}\text { ASG- } \\
\text { Health }\end{array}$ & 11 & 31 & 15 & 7 & 6 & 1.51 & 1.139 & 70 & 9 \\
\hline $\begin{array}{l}\text { ASG- } \\
\text { Retirement }\end{array}$ & 13 & 31 & 10 & 10 & 6 & 1.50 & 1.201 & 70 & 10 \\
\hline
\end{tabular}

Note: 0: Not Applicable; 1: Seldom; 2: Moderate; 3: Often; 5: Most often

While for variable price, there are six products that customers can choose which is Amanah Saham National (ASN), Amanah Saham National 2 (ASN 2), Amanah Saham National 3 Imbang (ASN 3), Amanah Saham Gemilang (ASG)-Education, Amanah Saham Gemilang (ASG)-Health and Amanah Saham Gemilang (ASG)-Retirement.

ASB is rank at the first as ASNB's products that respondents mostly heard with the mean of 3.23. Followed by ASW 2020 (2.73) at the second rank, ASM is rank at the third for ASNB products that heard by respondents with the mean of 2.46. At the fourth rank, respondents also heard an ASNB product which is ASN 2 with the average score of 2.04. At the fifth rank, respondents heard about ASN 3 with the average score of 2.01. On the sixth rank, respondents are heard about ASD with the mean of 2.00 .

For the seventh rank, with the mean of 1.64 shows those respondents are heard about ASN. Next at the eighth rank, with the mean of 1.57 shows those respondents heard about ASG-Education. Followed by ninth rank, respondents are heard about ASG-Health with the mean of 1.51 . Finally, at the tenth rank with the mean of 1.50, respondents are less heard about ASG-Retirement.

As a conclusion, the data shows that they are agree that they are heard about ASNB's product especially ASB, ASW 2020, ASM and ASN 2 but they are less heard about Amanah Saham Gemilang (ASG) especially Health, Education and Retirement.

Respondents' exposed to promotional strategies: Table 4 shows the frequency, mean, standard deviation and rank of promotional strategies used by ASNB to promote their products as perceived by respondents.
Table 4: Frequency, mean, standard deviation and rank for respondents' exposed to promotional strategies

\begin{tabular}{|c|c|c|c|c|c|c|c|c|c|}
\hline \multirow{2}{*}{$\begin{array}{l}\text { Promotional } \\
\text { Strategies }\end{array}$} & \multicolumn{5}{|c|}{ Scale } & \multirow[b]{2}{*}{ Mean } & \multirow{2}{*}{$\begin{array}{l}\text { Std. } \\
\text { Dev. }\end{array}$} & \multirow[b]{2}{*}{$\mathrm{n}$} & \multirow[b]{2}{*}{ Rank } \\
\hline & 0 & 1 & 2 & 3 & 4 & & & & \\
\hline $\begin{array}{l}\text { Bunting/ } \\
\text { banner/ } \\
\text { pamphlets }\end{array}$ & 0 & 13 & 21 & 25 & 11 & 3.49 & 0.974 & 70 & 6 \\
\hline $\begin{array}{l}\text { Newspapers/ } \\
\text { magazines }\end{array}$ & 1 & 9 & 20 & 30 & 10 & 3.56 & 0.942 & 70 & 5 \\
\hline Television & 4 & 17 & 28 & 16 & 5 & 3.01 & 1.000 & 70 & 10 \\
\hline Radio & 11 & 21 & 21 & 14 & 3 & 2.67 & 1.100 & 70 & 12 \\
\hline Internet & 11 & 20 & 26 & 9 & 4 & 2.64 & 1.077 & 70 & 13 \\
\hline $\begin{array}{l}\text { Personal } \\
\text { Selling }\end{array}$ & 0 & 27 & 31 & 11 & 1 & 2.80 & 0.754 & 70 & 11 \\
\hline Exhibition & 0 & 8 & 44 & 17 & 1 & 3.16 & 0.629 & 70 & 8 \\
\hline Seminar & 0 & 13 & 30 & 24 & 3 & 3.24 & 0.806 & 70 & 9 \\
\hline MSAM & 0 & 14 & 20 & 25 & 11 & 3.47 & 0.989 & 70 & 7 \\
\hline $\begin{array}{l}\text { Direct } \\
\text { Marketing }\end{array}$ & 70 & 0 & 0 & 0 & 0 & 1.00 & 0.000 & 70 & 14 \\
\hline $\begin{array}{l}\text { Bantuan } \\
\text { Khairat } \\
\text { Kematian }\end{array}$ & 1 & 3 & 13 & 28 & 25 & 4.04 & 0.924 & 70 & 1 \\
\hline $\begin{array}{l}\text { Dividend } \\
\text { /Bonus }\end{array}$ & 0 & 6 & 17 & 31 & 16 & 3.81 & 0.889 & 70 & 3 \\
\hline $\begin{array}{l}\text { Fixed and } \\
\text { Variable } \\
\text { Price }\end{array}$ & 0 & 6 & 19 & 28 & 17 & 3.80 & 0.910 & 70 & 4 \\
\hline $\begin{array}{l}\text { Products } \\
\text { Withdrawal } \\
\text { /Savings at } \\
\text { any time }\end{array}$ & 2 & 6 & 15 & 25 & 22 & 3.84 & 1.058 & 70 & 2 \\
\hline
\end{tabular}

Note: 0: Not applicable; 1: Seldom 2: Moderate, 3: Often, 5: Most Often

There are fourteen promotional strategies used by ASNB to promote their products such as from pamphlets, newspaper, magazines, television, radio, internet, personal selling, exhibition, seminar, Minggu Saham Amanah Malaysia (MSAM) and four of the sales promotion (bantuan khairat kematian, dividend/bonus, fixed and variable price and withdrawal/ savings at any time). Majority of respondents exposed to the sales promotion (as stated above) done by ASNB to promote their products. Next at the fifth rank, customers are exposed towards promotion done through newspapers/magazines with the average score of 3.56 .

At the sixth rank, customers are also exposed on the advertisement done through bunting/banner/pamphlets with the average score of 3.49. At the seventh rank, customers are exposed toward MSAM with the mean of 3.47. On the eighth rank, customers are exposed toward promotion done through exhibition with the mean of 3.16. For the ninth rank, with the mean of 3.24 shows those customers are exposed towards promotion done through seminar.

Furthermore, at the tenth rank with the average score of 3.01 shows that the customers are exposed 
towards promotion done by television. Followed by eleventh rank, customers are exposed of the existing of sales person or the personal selling offer by ASNB. Next at the twelfths rank, with the mean of 2.67 shows the customers are aware of promotion done through radio. Finally, at the thirteenth rank with the mean of 2.64, customers are less exposed about the promotion done through internet because most of them do not get the information from internet.

But for direct marketing, all of the respondents answered it is as never exposed to that promotional strategy which means that ASNB did not apply this strategy to motivate the people to invest in their products.

Perceived level of effectiveness towards promotion done: The attributes from Table 5 shows the perceived level of effectiveness towards promotion done through different promotional activities. From the Table 5, we can see majority of respondents perceived that sales promotion is very effective promotional activity with ranking at the first place. This mean, sales promotion is the most effective promotional tools done by ASNB. The sales promotion done by ASNB to motivate the people to invest in ASNB products included bantuan khairat kematian, dividend/bonus, fixed and variable price as well as withdrawal/ or savings at any time. Next at the second rank, promotions done through personal selling are very effective with the average score of 3.79 .

At the third rank, the advertising done through printed media (such as pamphlets, banner, bunting, newspaper and magazines) and also through electronic media (such as television, radio and internet via website) are very effective with the average score of 3.59. At the fourth rank public relations done by ASNB which is through Minggu Saham Amanah Malaysia (MSAM), seminar and exhibitions are very effective with the mean of 3.51 .

As a conclusion, the most effective promotional tool is through sales promotion done by ASNB in order to motivate the people to invest in ASNB. Thirty of respondents are agreed that the promotion done through such tool is very effective while only one of them said that sales promotion is not effective.

Correlations between promotional strategies and customer motivation: The Rules of thumb about the strength of correlation coefficient is if the r-value is $\pm 0.81-1.00$ (very strong), $\pm 0.61-0.80$ (strong), \pm 0.41 0.60 (moderate) and $\pm 0.21-0.40$ (weak) $^{[5]}$. Based on Table 6, by using the Pearson Correlation, the correlation coefficient between advertising and customer motivation is $r=0.374$. Therefore, there is a positive but weak relationship between advertising and customer motivation.

Next, the correlation coefficient between sales promotion and customer motivation is $\mathrm{r}=0.598$. Therefore, there is a positive and high relationship between sales promotion and customer motivation.

The correlation coefficient between personal selling and customer motivation is $r=0.31$. Therefore, there is a positive but low relationship between personal selling and customer motivation.

While the correlation coefficient between public relations and customer motivation is $r=0.130$. Therefore, there is a positive but low relationship between publicity and customer motivation.

$\mathbf{H}_{\mathbf{0 1}}$ : There is no significant correlation between customer motivation to invest in ASNB with the advertising.

Based on Table 6, by using the Pearson Correlation, the correlation coefficient between customer motivation and advertising is $r=0.374$. Therefore, there is a positive but weak relationship between customer motivation and advertising. Since $\mathrm{p}=0.001$ is less than $\alpha=0.05$, research hypothesis $\mathrm{H}_{\mathrm{A} 1}$ is failed to reject. Thus, there is a significant correlation between customer motivation and advertising at 0.05 level of significance.

Table 5: Perceived level of effectiveness towards promotion done through different promotional activities by frequency and percentage

\begin{tabular}{llllllllll}
\hline & \multicolumn{3}{l}{ Scale } & & & & & & \\
Promotional & ---------------- & \multicolumn{2}{l}{ Std. } \\
strategies & 1 & 2 & 3 & 4 & \multicolumn{1}{c}{ Mean } & Dev. & n & Rank \\
\hline Advertising & 1 & 5 & 28 & 24 & 12 & 3.59 & 0.909 & 70 & 3 \\
Personal selling & 0 & 4 & 23 & 27 & 16 & 3.79 & 0.866 & 70 & 2 \\
Sales promotion & 0 & 1 & 17 & 30 & 22 & 4.04 & 0.788 & 70 & 1 \\
Public relations & 2 & 3 & 26 & 35 & 4 & 3.51 & 0.794 & 70 & 4 \\
\hline
\end{tabular}

Note: 1: Strongly disagree; 2: Disagree; 3: Moderate; 4: Agree; 5: Strongly agree

Table 6: Correlations between promotional strategies and customer motivation

\begin{tabular}{llc}
\hline Variables & & Customer motivation \\
\hline Advertising & Pearson correlation & $0.374 * *$ \\
Mean: 3.46 & Sig. (2-tailed) & 0.001 \\
SD: 0.813 & N & 70.000 \\
Sales promotion & Pearson correlation & $0.598^{* *}$ \\
Mean: 3.92 & Sig. (2-tailed) & 0.000 \\
SD: 0.675 & N & 70.000 \\
Personal selling & Pearson correlation & 0.031 \\
Mean: 3.80 & Sig. (2-tailed) & 0.802 \\
SD: 0.805 & N & 70.000 \\
Public relations & Pearson correlation & 0.130 \\
Mean: 3.98 & Sig. (2-tailed) & 0.284 \\
SD: 0.736 & N & 70.000 \\
\hline$* *$ Correlation is significant at the 0.05 level (2-tailed)
\end{tabular}


Table 7: Regression of advertising and sales promotion towards customer motivation

\begin{tabular}{llll}
\hline Variables & $\mathrm{B}$ & Significant & $\mathrm{N}$ \\
\hline Constant & $1.708^{*}$ & 0.004 & 70 \\
Advertising & 0.017 & 0.877 & 70 \\
Sales promotion & $0.603^{*}$ & 0.000 & 70 \\
\hline
\end{tabular}

Note: A dependent variable: Customer motivation *: Significant at $\mathrm{p}<0.05 ;{ }^{\text {ns }}$ : Not significant at $\mathrm{p}>0.05$

$\mathbf{H}_{\mathbf{0} 2}$ : There is no significant correlation between customer motivation to invest in ASNB with the sales promotion.

Based on Table 6, by using the Pearson Correlation, the correlation coefficient between customer motivation and sales promotion is $\mathrm{r}=0.598$. Therefore, there is a positive and high relationship between customer motivation and sales promotion. Since $\mathrm{p}=0.000$ is less than $\alpha=0.05$, research hypothesis, $\mathrm{H}_{\mathrm{A} 2}$ is failed to reject. Thus, there is a significant correlation between customer motivation and sales promotion at 0.05 level of significance.

$\mathbf{H}_{\mathbf{0} 3}$ : There is no significant correlation between customer motivation to invest in ASNB with the personal selling.

Based on Table 6, by using the Pearson Correlation, the correlation coefficient between customer motivation and personal selling is $r=0.031$. Therefore, there is a positive but low relationship between customer motivation and personal selling. Since $p=0.284$ is more than $\alpha=0.05$, null hypothesis, $\mathrm{H}_{03}$ is failed to reject. Thus, there is no significant correlation between customer motivation and personal selling at 0.05 level of significance.

$\mathbf{H}_{\mathbf{0 4}}$ : There is no significant correlation between customer motivation to invest in ASNB with the public relations.

Based on Table 6, by using the Pearson Correlation, the correlation coefficient between customer motivation and public relations is $\mathrm{r}=0.130$. Therefore, there is a positive but low relationship between customer motivation and public relations. Since $\mathrm{p}=0.284$ is more than $\alpha=0.05$, null hypothesis, $\mathrm{H}_{04}$ is failed to reject. Thus, there is no significant correlation between customer motivation and public relations at 0.05 level of significance.

Regression Analysis on Effect of Promotional Strategies with Customer Motivation to Invest in ASNB

Regression results: Table 7 shows the regression of advertising and sales promotion towards customer motivation to invest in ASNB's products.

Both independent variables are significant where the effectiveness of sales promotion is highly significant with $p<0.00$ while the beta value is 0.603 which mean there is positive effect between promotion done through sales promotion towards customer motivation to invest.

It explains the more sales promotion done by ASNB to promote their products such as 'bantuan khairat kematian', dividend/bonus, withdrawal/savings at any time as well as fixed and variables price products, the more motivation for customers to invest in ASNB products thus can increase sales of ASNB.

While effectiveness of advertising is poor significant effect with $p>0.877$ while the beta value is 0.017 which mean there is no effect between promotion done through advertising by ASNB towards customer motivation to invest in their products. It means when ASNB used advertising through printed and electronic media (such as: Pamphlets, bunting, billboards, television and radio) as well as internet (via website), the less motivation for customers to invest in ASNB.

As a conclusion, the findings explains that among four tools used by ASNB which is sales promotion, advertising, personal selling and public relations to promote their products, only sales promotion has high significant effect towards customer motivation to invest.

$\mathbf{H}_{\mathbf{0} 5}$ : There is no significant effect between advertising towards customer motivation to invest in ASNB.

After the hypothesis being tested, (Table 7) it is found that the value of beta is at 0.017 with the significant value of 0.877 . Since the significant value is $\mathrm{p}>0.05, \mathrm{H}_{\mathrm{A} 5}$ will be rejected. This means that the customer motivation to invest is significantly not influenced by the effectiveness of advertising.

$\mathbf{H}_{\mathbf{0 6}}$ : There is no significant effect between sales promotions towards customer motivation to invest in ASNB.

After the hypothesis being tested, (Table 7) it is found that the value of beta is at 0.603 with the significant value of 0.000 . Since the significant value is $\mathrm{p}<0.05, \mathrm{H}_{\mathrm{A} 6}$ failed to rejected. This means that the customer motivation to invest is significantly influenced by the effectiveness of sales promotion.

\section{DISCUSSION}

From the result, the following can be concluded. The beta value for the variables of effectiveness of advertising, personal selling and public relations are perverse. Thus there are inverse significantly relationships between the customer motivation to invest with the effectiveness of advertising. The effectiveness 
of advertisement through printed and electronic media as well as internet also does not support the customer motivation to invest in ASNB products ${ }^{[1]}$. This may due to the advertisement publish were not attractive enough to encourage them to invest. From previous study, advertising see as the best promotional medium in order to persuade consumer. This situation occurs may due to several reasons such as, the respondents who are busy does not have time to watch television and radio, the printed media did not gave sufficient enough information about the products and many other reasons.

Moreover, the more promotions done through personal selling is the less the customer motivation to invest in ASNB products. This mean the promotion done through personal selling are not effective enough to motivate investors to invest in ASNB products ${ }^{[7]}$. These situations happened due to inexperienced sales person or the sales person did not really persuade the customers to invest in ASNB. This is contradicting with the previous findings and further research may need in order to know deeper about the fact.

The promotion done by public relations such as through seminar, exhibitions and Minggu Saham Amanah Malaysia (MSAM) also not motivate the customer to invest in ASNB products ${ }^{[8]}$. From the Beta value, this promotion tool has negative relationship with the motivation to invest. The more ASNB put effort on the effectiveness of public relations; the less it can motivate customers to invest in ASNB products. Nevertheless, ASNB can motivate customers or investors to invest in ASNB products through sales promotion since it has the positive significantly relationship with the customer motivation to invest in ASNB's products. It means the more effective of scheme 'bantuan khairat kematian', offer fixed and variable price, high income distribution/bonus and offer withdrawal/savings at any time as promotional tool, the more in can motivate the customers to invest in ASNB's products ${ }^{[9]}$.

The model that can be adapted from the research is:

$\mathrm{Y}=1.078+0.603 \mathrm{SP}$

Where:

$\mathrm{Y}=$ Customer motivation

Constant $=1.078$

$\mathrm{SP} \quad=$ Sales Promotion

Recommendations: From the analyses done and the findings, several recommendation strategies can be suggested. The strategies are designed for the future research and for further development and improvement for Permodalan National Berhad generally and Amanah Saham National Berhad specifically:
- Sales promotion can be seen as the most promotional strategies that have high effect towards customer motivation to invest. Thus, ASNB should increase their promotion through this method because investors are more attracted to the promotion especially in term of income distribution/dividend and the uniqueness of the products itself. As we know, ASNB is the only unit trust company in the world that offered fixed price products and the lowest investment which start from RM 10 only. In addition, the dividend should be increase year by year and this can be seen as great news to the investors since ASNB is the established company in Malaysia and the dividend is high compared to the competitors ${ }^{[10]}$

- Newspapers are among the best promotional strategy in order to attract intentions from investors. From that fact, ASNB should build up more public relation by sharing news or information through newspapers. ASNB should advertise their products frequently in newspaper therefore people can get to know about their products. There are more than 80,000 newspapers' readers all over Malaysia for one brand of newspaper. There are several famous newspapers' brand among Malaysian, therefore ASNB can used same messages for different brand of newspapers. Newspapers can grab broader target audience since people read newspaper everyday

- Since the advertisement through television is less attractive to motivate investors in invest in ASNB, ASNB have to put an effort to increase the level of effectiveness of their television advertisement. ASNB should focus on how to attract customers to buy ASNB's products. ASNB have to create advertisement that can really motivate people to invest in their products. This strategy has to go inline with the creativity of people who creating the advertisement as well as the target market for the products. For example, for ASG product PNB had a sales promotion by giving extra unit if investors buy certain units of the product. PNB should advertise this kind of promotion in television therefore people are aware instead of using brochures where not all people will get the brochures $^{[11]}$

- As stated in previous section, MSAM is one of the promotion through publicity which also can motivate customers to invest in Amanah Saham National Berhad. But, ASNB should put more effort on this strategy since it can attract more investors to buy ASNB's products. ASNB should continue the MSAM program which has been 
doing every year. Furthermore, MSAM also one of the medium that can makes people gain knowledge about ASNB's products. At present, ASNB only had the MSAM once a year, since it can encourage more investors to invest PNB should plan to have at least twice a year. The area cover can be broader. For example, year 2007 ASNB had the MSAM at Pahang Darul Makmur which covers areas such as Pahang, Perak, Kelantan, Terengganu and Kelantan. If ASNB separate the area cover such as MSAM in Pahang early of the year and middle of the year ASNB can have it in Malacca, people who come to MSAM would be more. The possibility of people to invest in ASNB products also would be much higher ${ }^{[12]}$

- Amanah Saham National Berhad should see sales executives as their assets since investors see them as effective strategy in persuading them to invest in ASNB. If possible, the study suggests that ASNB should employ more sales executives; therefore they can bring more investors to ASNB. Besides that, ASNB have to give training to their sales executives as well as give them motivation to excel

- From researcher observation, majority of management companies of unit trust are using individual agents in order to promote and sell the companies' products. In ASNB, there are no individual agents being employed. The function of individual agents is the same with sales executives where they have to persuade people to invest in ASNB products. The different is sales executives only get the salary where as individual agents earn income from commission. The actual fact is people tend to find more customers if they get more. Therefore, ASNB has to appoint individual agents in order to boost up ASNB sales 13

\section{CONCLUSION}

Most of the respondents invest in one out of ten products of ASNB. But there are also respondents who invest in more than one product. While in terms of promotional strategies used by ASNB, the most effective is through sales promotion such as income distribution/dividend, fixed and variables price products and withdrawal/savings at any time followed by advertising via printed and electronic media as well as through internet. Since respondents are invest in ASNB's products and they are agreed that most of the promotional strategies implement by ASNB's are effective therefore they are motivated to invest in ASNB's product because of the promotional done.
Even though not all the strategies used by the company are effective but overall we can see that the promotional done is effective to motivate the investors.

\section{ACKNOWLEDGEMENT}

The researchers would like to thank MOSTIC, Research Management Centre (RMC) and University Technology Malaysia. The researchers also wish to thank lecturers and friends for many helpful ideas and discussion.

\section{REFERENCES}

1. Shamsher, M. and M.N. Annuar, 2001. Investments in Unit Trusts: Should Investors Choose Active or Passive Funds? The Company Secretary. Journal of the Malaysian Association of The Institute of Chartered Secretaries and Administrators.

2. Malhotra, N.K., 2001. Basic Marketing ResearchApplication to Contemporary Issues. International Edition, Prentice Hall, USA., ISBN: 10: 0133768562, pp: 685.

3. Wise, R and N. Sirohi, 2005. Finding the best marketing mix. J. Bus. Strat., 26: 10-11. DOI: 10.1108/02756660510632975

4. Sekaran, U., 2003. Research Methods for Business: A Skill Building Approach. 4th Edn., John Wiley and Sons Inc., ISBN: 0471618896, pp: 448.

5. Hair, J.F., R.P. Bush and D.J. Ortinau, 2003. Marketing Research within a Changing Information Environment. 4th Edn., Pearson Education Ltd., United States of America, ISBN: 0071151192, pp: 672.

6. Taib, F.M. and M. Isa, 2007. Malaysian unit trust aggregate performance. Manage. Finance, 33: 102-121. DOI: $10.1108 / 03074350710715836$

7. Ndubisi, N.O. and T.M. Chew, 2006. Awareness and usage of promotional tools by malaysian consumers: The case of low involvement products. Manage. Res. News, 29: 28-40. http://www.emeraldinsight.com/Insight/ViewConte ntServlet?Filename=/published/emeraldfulltextartic le/pdf/0210290103.pdf

8. Henriksson, R.T., 1984. Market timing and mutual funds performance: An empirical investigation. J. Bus., 57: 73-96. http://ideas.repec.org/a/ucp/jnlbus/v57y1984i1p7396.html 
9. Jordan, J. and K.P. Kaas, 2002. Advertising in the mutual fund business: The role of judgmental heuristic in private investors' evaluation of risk and return. J. Financ. Service Mark., 17:129-140. DOI: 10.1057/palgrave.fsm.4770079

10. Zikmund, W.G., 2007. A Strategic Perspective on Sales Promotions. MIT Press, Sloan Management Review, Cambridge, ISBN: 8131502810, pp: 123-144.
11. Permodalan National Berhad Annual Report, 2007. Kuala Lumpur, Malaysia. pp: 23-26.

12. Permodalan National Berhad, 2001. Malaysia Unit Trust directory. Permodalan National Berhad, Kuala Lumpur pp: 78-79. 